\title{
Mffedia \\ PENGARUH EKSTRAK DAUN PARE (Momordica charantia L.) TERHADAP PERTUMBUHAN Streptococcus pneumonia, Staphylococcus epidermidis, Staphylococcus aureus dan Klebsiella pneumonia PENYEBAB INFEKSI SALURAN PERNAPASAN AKUT
}

\section{The Effect Of Bitter Melon Leaf Extract (Momordica charantia L.) Towards The Growth Of Streptococcus pneumonia, Staphylococcus epidermidis, Staphylococcus aureus And Klebsiella pneumonia As A Cause Of Acute Respiratory Infections}

\author{
Sesilia Rante Pakadang*, Hiany Salim \\ Jurusan Farmasi Politeknik Kesehatan Kemenkes Makassar \\ *Koresponden Email : mamajassy@gmail.com
}

DOI: https://doi.org/10.32382/mf.v16i2.1802

\section{ABSTRACT}

Acute Respiratory Infection (ARI) is a contagious disease that affects the respiratory tract organs such as the sinuses, middle ear cavity until the pleura. Streptococcus pneumoniae, Klebsiella pneumonia, Staphylococcus aureus and Staphylococcus epidermidis are bacteria that causes ARI. This research aums to determine the effect of bitter melon leaf extract (Momordica charantia L.) on the growth of Streptococcus pneumoniae, Klebsiella pneumonia, Staphylococcus aureus and Staphylococcus epidermidis, which causes ISPA by measuring the inhibition zone of these bacteria growth. The bitter melon (Momordica charantia L.) leaf extract was prepared by maceration using $96 \%$ ethanol solvent and tested for its bacterial growth inhibitory using the disc diffusion agar method with MHA media. Furthermore, the extract was made with a concentration of 5,000 ppm, 10,000 ppm and 15,000 ppm as well as with a comparison of 50 ppm amoxicillin and control of $\mathrm{Na} \mathrm{CMC}$. The results showed that the mean bacterial growth inhibitory $(\mathrm{mm})$ of the test material respectively at concentrations of 5,000 ppm, 10,000 ppm, 15,000 ppm, amoxicillin 50 ppm and Na CMC: for Streptococcus pneumoniae were 9,36; 12; 13,53; 17,75; 0. For Staphylococcus aureus were 16,82; 17,82; 22,24; 21,61; 0. For Staphylococcus epidermidis were 16,99; 18,78; 21,81; 22,11; 0. And for Klebsiella pneumonia were 11,82; 13,45; 14,7; 15,88; 0. Conclusion; Bitter melon leaf extract (Momordica charantia L.) influences the growth of Streptococcus pneumoniae, Klebsiella pneumoniae, Staphylococcus aureus and Staphylococcus epidermidis as the cause of ARI.

Keywords: bitter melon leaf, Streptococcus pneumoniae, Klebsiella pneumonia, Staphylococcus aureus, Staphylococcus epidermidis, ARI

\begin{abstract}
ABSTRAK
Infeksi Saluran Pernapasan Akut (ISPA) adalah penyakit infeksi yang menyerang organ saluran napas seperti sinus, rongga telinga tengah hingga pleura. Streptococcus pneumoniae, Klebsiella pneumonia, Staphylococcus aureus dan Staphylococcus epidermidis penyebab ISPA adalah beberapa bakteri yang sering ditemukan sebagai penyebab ISPA. Tujuan penelitian ini adalah menentukan pengaruh Ekstrak Daun Pare (Momordica charantia L.) terhadap pertumbuhan bakteri Streptococcus pneumoniae, Klebsiella pneumonia, Staphylococcus aureus dan Staphylococcus epidermidis penyebab ISPAdengan mengukur zona hambat pertumbuhan bakteri tersebut. Ekstrak Daun Pare (Momordica charantia L.) dibuat dengan cara maserasi menggunakan pelarut etanol $96 \%$ dan diuji daya hambat pertumbuhan bakteri menggunakan metode disc diffusion agar menggunakan media MHA. Ekstrak daun pare dibuat dengan konsentrasi 5.000 ppm, 10.000 ppm dan 15.000 ppm dengan pembanding amoksisilin 50 ppm dan kontrol Na CMC. Hasil penelitian menunjukkan bahwa rerata daya hambat $(\mathrm{mm})$ pertumbuhan bakteri berturut-turut untuk bahan uji ekstrak daun pare konsentrasi 5.000 ppm, 10.000 ppm, 15.000 ppm, amoksisilin 50 ppm dan Na CMC: untuk Streptococcus pneumoniae adalah 9,36;12;13,53; 17,75; 0. Untuk Staphylococcus aureus adalah 16,$82 ; 17,82 ; 22,24 ; 21,61 ; 0$. Untuk Staphylococcus epidermidis adalah 16,99; 18,78; 21,81; 22,11; 0. Untuk Klebsiella pneumonia adalah 11,$82 ; 13,45 ; 14,7 ; 15,88 ; 0$. Kesimpulan; ekstrak daun pare (Momordica charantia L.) berpengaruh terhadap pertumbuhan bakteri Streptococcus pneumoniae, Klebsiella pneumonia, Staphylococcus aureus dan Staphylococcus epidermidis penyebab ISPA.
\end{abstract}

Kata kunci: daun pare, Streptococcus pneumoniae, Klebsiella pneumonia, Staphylococcus aureus, Staphylococcus epidermidis, ISPA 


\section{PENDAHULUAN}

Infeksi Saluran Pernapasan Akut (ISPA) adalah penyakit infeksi akut yang menyerang salah satu organ saluran napas seperti sinus, rongga telinga tengah hingga pleura. Insidens ISPA di negara berkembang pada Balita diprediksi 0,29 kali per anak per tahun sedangkan di negara maju 0,05 kali per anak setiap tahun. Hal ini berarti terjadi 156 juta episode baru per tahun di dunia dan data menunjukkan 151 juta kejadian $(96,7 \%)$ terjadi di beberapa negara berkembang. Kasus tertinggi terjadi di India (43 juta), China (21 juta) dan Pakistan (10 juta). Selanjutnya Bangladesh, Indonesia, Nigeria masing-masing menyumbang 6 juta kejadian. Menurut data WHO, kejadian batuk-pilek sebagai manifestasi awal ISPA pada Balita di Indonesia terjadi 2-3 kali per tahun. ISPA menyumbang penyebab kunjungan pasien di Puskesmas 40\%-60\% dan 15\%-30\% di rumah sakit. Strategi pencegahan dan pengendalian ISPA diimplementasi dalam berbagai program nasional bidang Kesehatan periode 2015-2019. Salah satu strategi adalah pendekatan keluarga untuk melakukan deteksi dini dan pengobatan segera, serta upaya preventif \& promotif untuk mengendalikan faktor risiko ISPA (Kemenkes RI, 2016).

Fasilitas pelayanan kesehatan menemui tantangan untuk menyiapkan pelayanan terhadap penyakit akut dan kronis karena membutuhkan pelayanan jangka waktu lama dan biaya mahal. Kesuksesan pengendalian ISPA tergantung kinerja fasilitas pelayanan kesehatan dengan dukungan cukupnya sumber daya. Komitmen tenaga kesehatan dan pelaksanaan strategi kebijakan yang terintegrasi, komprehensif dan berkesinambungan. Upaya penanggulangan ISPA memerlukan dukungan lintas unit kerja di Kementerian Kesehatan, lintas sektor yang didukung keterlibatan masyarakat, akademisi, profesional dan dunia usaha dan dukungan politis harus dilakukan secara komprehensif mulai dari upaya promotif, preventif, kuratif dan rehabilitatif (Kemenkes RI, 2011). Peran masyarakat menjadi bagian dari peran akademisi dalam pelatihan kader Kesehatan, desa siaga, posyandu, untuk mengenal tanda pneumonia dan upaya pencegahannya. Salah satu peran akademisi khususnya bidang farmasi adalah penyediaan bahan untuk pencegahan dan pengobatan ISPA secara dini yang dapat dilakukan oleh masyarakat secara mandiri sebelum ke sarana pelayanan Kesehatan.

Salah satu upaya pencegahan dan pengobatan penyakit yang didasari oleh kearifan local masyarakat Indonesia adalah obat tradisional. Obat tradisional telah dipercaya secara empiris dalam pengobatan penyakit. Pembuktian ilmiah terhadap efektivitas obat tradisional telah banyak pula dilakukan. Pengobatan berbagai tanaman untuk pengobatan ISPA telah terbukti secara empiris, salah satunya adalah daun pare (Momordica charantia L.). Secara empiris daun pare telah banyak digunakan sebagai obat batuk berdahak yang merupakan ciri utama penyakit ISPA. Gejala umum ISPA adalah batuk yang sering disertai lender. Sebagaimana penyakit infeksi lainnya ISPA juga disebabkan oleh berbagai mikroorganisme terutama bakteri. Ekstrak daun pare diketahui mengandung flavonoid, alkaloid, saponin dan triterpenoid yang memiliki sifat antibakteri (Aulya, 2012). Aktivitas antibakteri daun pare telah banyak dilakukan terhadap bakteri Salmonella typhi, Staphylococcus aureus, Propionibacterium acnes, Shigella dysenteriae. Namun pembuktian ilmiah terhadap bakteri penyebab ISPA belum terpublikasi dalam beberapa tahun terakhir. Untuk meningkatkan kepercayaan masyarakat dan dunia medis akan khasiat daun pare sebagai herbal untuk pencegah dan pengobatan ISPA maka perlu dilakukan pembuktian ilmiah.

Pakadang dkk (2018) telah mengisolasi bakteri dari sputum penderita ISPA non tuberkulosis di RS Ibnu Sina Makassar. Hasil kultur ditemukan 5 jenis bakteri yaitu: Streptococcus pneumonia, Klebsiella pneumonia, Staphylococcus aureus, , Staphylococcus epidermidis, Enterobacter agglomerans dan 1 jenis jamur yaitu Candida albicans. Bakteri yang paling umum ditemukan pada sampel penderita ISPA adalah Streptococcus pneumonia, Staphylococcus aureus, Klebsiella pneumonia dan Staphylococcus epidermidis. Sehingga pembuktian ilmiah tentang pengaruh pemberian ekstrak daun pare (Momordica charantia L.) dalam menghambat dan membunuh pertumbuhan bakteri-bakteri penyebab ISPA menjadi tujuan penelitian ini.

\section{METODE}

Bahan uji yang digunakan adalah ekstrak daun pare. Daun pare diekstraksi dengan metode maserasi menggunakan pelarut etanol 96\% dan dipekatkan dengan rotary evaporator. Rendemen simplisia basah - simplisia kering hingga ekstrak dihitung dalam persentase.

Ekstrak disuspensikan dengan Na CMC menjadi konsentrasi 5.000 ppm; 10.000 ppm dan 15.000 ppm. Konsentrasi 50.000 ppm disiapkan dengan mengsuspensikan $50 \mathrm{mg}$ ekstrak daun pare dalam $10 \mathrm{ml} \mathrm{Na}$ CMC 1\%. Demikian pula untuk konsentrasi 10.000 dan 15.000 ppm 
dengan menimbang 100 dan 150 mg ekstrak daun pare. Kontrol positif yang digunakan yaitu antibiotik ampicillin $50 \mathrm{ppm}$ dan kontrol negatif yang digunakan yaitu Na CMC $1 \%$

Pengujian aktivitas daya hambat pertumbuhan bakteri secara in vitro menggunakan media Mueller Hinton Agar (MHA) dengan metode difusi agar menggunakn paper disc.

Bakteri uji yang digunakan adalah hasil peremajaan isolate bakteri dari kultur sputum penderita ISPA non tuberkulosis. Bakteri uji yang digunakan adalah Streptococcus pneumonia, Staphylococcus epidermidis, Staphylococcus aureus dan Klebsiella pneumonia. Bakteri uji disuspensikan dalam air steril dan diencerkan hingga sesuai dengan tingkat kekeruhan standar Mc Farland 0,5. Pengujian dilakukan dengan masa inkubasi 1-2 x 24 jam.

\section{Pengolahan dan analisis data}

Analisis data hasil pengukuran zona hambat pertumbuhan bakteri uji Streptococcus pneumonia, Staphylococcus epidermidis, Staphylococcus aureus dan Klebsiella pneumonia diolah menggunakan program SPSS non parametric Kruskal Wallis dan Mann Whitney untuk menentukan perbedaan pengaruh konsenstrasi ekstrak daun pare terhadap pertumbuhan bakteri uji.

\section{HASIL}

Hasil perhitungan rendemen simplisia dan ekstrak daun pare (Momordica charantia L.) adalah sebagai berikut: Daun pare basah 1000 gram menjadi $200 \mathrm{~g}$ daun pare kering (simplisia daun pare). Rendemen simplisia kering terhadap daun pare basah adalah $20 \%$. Simplisia daun pare 100 gram diekstraksi menjadi 3,47 gram ekstrak kental daun pare. Rendemen ekstrak kental terhadap simplisia daun pare adalah $3,47 \%$.

Tabel 1. Hasil pengukuran daya hambat ekstrak daun pare (Momordica charantia L.) terhadap pertumbuhan bakteri Streptococcus pneumoniae, Staphylococcus epidermidis, Staphylococcus aureus dan Klebsiella pneumonia

\begin{tabular}{lccccc}
\hline Bahan uji & Replikasi & \multicolumn{3}{c}{ Diameter zona hambat pertumbuhan bakteri (mm) } & \\
\cline { 3 - 6 } & & $\begin{array}{c}\text { Streptococcus } \\
\text { pneumoniae }\end{array}$ & $\begin{array}{c}\text { Staphylococcus } \\
\text { epidermidis }\end{array}$ & $\begin{array}{c}\text { Staphylococcus } \\
\text { aureus }\end{array}$ & $\begin{array}{c}\text { Klebsiella } \\
\text { pneumonia }\end{array}$ \\
\hline Ekstrak daun & 1 & 9,56 & 17,34 & 16,43 & 13,13 \\
pare 5.000 ppm & 2 & 8,68 & 16,76 & 16,78 & 11,48 \\
& 3 & 9,85 & 16,89 & 17,26 & 10,87 \\
& Rerata & 9,36 & 16,99 & 16,82 & 11,82 \\
\hline Ekstrak daun & 1 & 13,22 & 17,87 & 17,24 & 13,23 \\
pare 10.000 & 2 & 11,87 & 18,57 & 18,59 & 12,58 \\
ppm & 3 & 10,93 & 19,68 & 17,64 & 14,54 \\
& Rerata & 12,00 & 18,78 & 17,82 & 13,45 \\
\hline Ekstrak daun & 1 & 14,13 & 22,88 & 22,14 & 14,68 \\
pare 15.000 & 2 & 13,58 & 20,86 & 23,21 & 13,87 \\
ppm & 3 & 12,89 & 21,69 & 21,39 & 15,56 \\
& Rerata & 13,53 & 21,81 & 22,24 & 14,70 \\
\hline Amoksisilin 50 & 1 & 17,34 & 21,58 & 20,87 & 16,11 \\
ppm & 2 & 16,79 & 22,87 & 21,39 & 16,45 \\
& 3 & 19,14 & 21,89 & 22,59 & 14.86 \\
& Rerata & 17,75 & 22,11 & 21,61 & 15,88 \\
\hline Na CMC 1\% & 1 & 0 & 0 & 0 & 0 \\
& 2 & 0 & 0 & 0 & 0 \\
& 3 & 0 & 0 & 0 & 0 \\
\hline
\end{tabular}

Tabel 2. Hasil analisis Mann Whitney pengaruh konsentrasi ekstrak daun pare terhadap zona hambat pertumbuhan bakteri uji

\begin{tabular}{lllllll}
\hline Perlakuan & & \multicolumn{6}{l}{ Zona hambat pertumbuhan bakteri uji } \\
\cline { 3 - 7 } Konsentrasi & $\mathrm{n}$ & Mean & Std dev & Median & Min & Max \\
\hline $5.000 \mathrm{ppm}$ & 12 & 13,75 & 3,47 & $14,78^{\mathrm{a}}$ & 11,54 & 15,96 \\
$10.000 \mathrm{ppm}$ & 12 & 15,50 & 3,06 & $15,89^{\mathrm{a}}$ & 13,56 & 17,45 \\
$15.000 \mathrm{ppm}$ & 12 & 18,07 & 4,22 & $18,21^{\mathrm{b}}$ & 15,39 & 20,75 \\
Amoksisilin & 12 & 19,32 & 2,86 & $20,00^{\mathrm{b}}$ & 17,50 & 21,14 \\
\hline
\end{tabular}


Superscript ${ }^{\mathrm{a}, \mathrm{b}}$ menunjukkan tidak ada perbedaan antar kelompok perlakuan (berdasarkan uji Mann Whitney)

Tabel 3. Hasil analisis LSD pengaruh ekstrak daun pare terhadap perbedaan zona hambat pertumbuhan bakteri uji

\begin{tabular}{lllllll}
\hline Jenis bakteri uji & \multicolumn{6}{l}{ Zona hambat pertumbuhan bakteri uji } \\
\cline { 3 - 7 } & $\mathrm{n}$ & Mean & Std dev & Median & Min & Max \\
\hline Streptococcus pneumoniae & 15 & 10,53 & 6,18 & $11.87^{\mathrm{a}}$ & 7,11 & 13,96 \\
Staphylococcus epidermidis & 15 & 15,92 & 8,49 & $18,57^{\mathrm{a}}$ & 11,21 & 20,63 \\
Staphylococcus aureus & 15 & 15,70 & 8,43 & $17,64^{\mathrm{a}}$ & 11,03 & 20,37 \\
Klebsiella pneumonia & 15 & 11,15 & 5,98 & $13,23^{\mathrm{a}}$ & 7,84 & 14,46 \\
\hline
\end{tabular}

Superscript ${ }^{a}$ menunjukkan tidak ada perbedaan zona hambat antar bakteri uji (berdasarkan uji LSD)

\section{PEMBAHASAN}

Hasil penelitian menunjukkan kemampuan bahan uji ekstrak daun pare (Momordica charantia L.) dalam menghambat pertumbuhan bakteri Streptococcus pneumoniae, Klebsiella pneumonia, Staphylococcus aureus dan Staphylococcus epidermidis. Hal ini terbukti dengan terbentuknya zona hambat (daerah bening) di sekitar paper disc yang mengandung bahan uji. Hasil pengujian menunjukkan semua bahan uji memberikan pengaruh terhadap pertumbuhan setiap bakteri uji. Demikian pula konsentrasi bahan uji ekstrak daun pare juga memberikan berpengaruh yang berbeda terhadap besarnya zoan hambat. Data zona hambat menunjukkan bahwa semakin besar konsentrasi bahan uji maka semakin besar pula zona pertumbuhan masing-masing bakteri uji yang dihambat. Hal ini disebakan karena besarnya konsentrasi bahan uji berarti semakin besar pula kandungan zat aktifnya. Data penelitian juga menunjukkan bahwa setiap bakteri uji mempunyai sensitivitas yang berbeda terhadap bahan uji. Hal ini ditunjukkan oleh diameter zona hambat yang bervariasi dari setiap bahan uji yang berbeda.

Penelitian ini menggunakan ekstrak daun pare. Proses penyarian menggunakan metode maserasi. Proses maserasi secara berulang memungkinkan seluruh zat aktif yang terkandung dalam simplisia akan tersari secara sempurna. Penggunaan etanol $96 \%$ sebagai cairan penyari didasari oleh sifat semipolar yang dimiliki etanol sehingga memungkinkan dapat menyari sebagaian besar komponen kimia dalam simplisia daun pare.

Pengujian pengaruh ekstrak daun pare (Momordica charantia L.) terhadap pertumbuhan bakteri Streptococcus pneumoniae, Klebsiella pneumonia, Staphylococcus aureus dan Staphylococcus epidermidis dilakukan dengan SPSS analisis ANOVA dan LSD. Analisis menunjukkan data berdistribusi normal dengan nilai normalitas 0,39 - 0,954 dan data homogen dengan nilai homogenitas 0,097 -
0,148 . Sehingga pengujian dilakukan dengan uji parametrik Anova. Hasil analisis menunjukkan nilai signifikan 0,000 untuk semua zona hambat pertumbuhan bakteri. Hal ini berarti bahan uji berpengaruh dalam menghambat pertumbuhan bakteri uji Streptococcus pneumoniae, Klebsiella pneumonia, Staphylococcus aureus dan Staphylococcus epidermidis. Selanjutnya pengujian dilanjutkan dengan uji LSD untuk menentukan perbedaan antar bahan uji.

Hasil uji LSD pengaruh bahan uji ekstrak daun pare terhadap pertumbuhan bakteri Streptococcus pneumoniae menunjukkan bahwa semua bahan uji memberikan pengaruh yang berbeda dalam menghambat pertumbuhan Streptococcus pneumoniae, kecuali antara ekstrak daun pare 10.000 ppm dengan 15.000 ppm. Hal ini menunjukkan potensi ekstrak daun pare $10.000 \mathrm{ppm}$ yang tidak berbeda nyata dengan potensi ekstrak daun pare $15.000 \mathrm{ppm}$.

Hasil uji LSD pengaruh bahan uji ekstrak daun pare terhadap pertumbuhan bakteri Staphylococcus epidermidis menunjukkan bahwa semua bahan uji memberikan pengaruh yang berbeda dalam menghambat pertumbuhan Staphylococcus epidermidis, kecuali antara ekstrak daun pare 15.000 ppm dengan amaoksisilin $50 \mathrm{ppm}$. Hal ini menunjukkan potensi ekstrak daun pare $15.000 \mathrm{ppm}$ yang tidak berbeda nyata dengan potensi antibiotika amoksisilin 50 ppm.

Hasil uji LSD pengaruh bahan uji ekstrak daun pare terhadap pertumbuhan bakteri Staphylococcus aureus menunjukkan bahwa semua bahan uji memberikan pengaruh yang berbeda dalam menghambat pertumbuhan Staphylococcus aureus, kecuali antara ekstrak daun pare $5.000 \mathrm{ppm}$ dengan ekstrak daun pare $10.000 \mathrm{ppm}$ dan ekstrak daun pare $15.000 \mathrm{ppm}$ dengan amoksisilin 50 ppm. Hal ini menunjukkan potensi ekstrak daun pare 15.000 ppm yang tidak berbeda nyata dengan potensi antibiotika amoksisilin $50 \mathrm{ppm}$. Demikian pula potensi ekstrak daun pare 5.000 ppm yang tidak 
berbeda nyata dengan potensi ekstrak daun pare $10.000 \mathrm{ppm}$.

Hasil uji LSD pengaruh bahan uji ekstrak daun pare terhadap pertumbuhan bakteri Klebsiella pneumonia menunjukkan bahwa semua bahan uji memberikan pengaruh yang berbeda dalam menghambat pertumbuhan Klebsiella pneumonia, kecuali antara ekstrak daun pare 10.000 ppm dengan ekstrak daun pare 15.000 ppm dan ekstrak daun pare 15.000 ppm dengan amoksisilin 50 ppm. Hal ini menunjukkan potensi ekstrak daun pare 15.000 ppm tidak berbeda nyata dengan potensi antibiotika amoksisilin $50 \mathrm{ppm}$. Demikian pula potensi ekstrak daun pare 10.000 ppm yang tidak berbeda nyata dengan potensi ekstrak daun pare 15.000 ppm.

Pengujian perbedaan efektivitas masing-masing konsentrasi ekstrak daun pare terhadap semua bakteri uji ditunjukkan oleh tabel 2. Analisis Kruskal Wallis menunjukkan nilai sig $\mathrm{p}=0,000$. Analisis Mann Whitney pada taraf 0,005 menyatakan bahwa konsentrasi 5.000 ppm dengan 10.000 ppm tidak berbeda nyata. Demikian pula konsentrasi 15.000 ppm dengan Hasil analisis menyimpulkan bahwa konsentrasi 15.000 ppm merupakan konsentrasi yang optimal dalam penelitian ini karena tidak berbeda nyata dengan control positif amoksisilin.

Tabel 3 menunjukkan hasil pengujian efektivitas ekstrak daun pare terhadap bakteri uji. Hasil pengujian menunjukkan ekstrak daun pare memberikan efektivitas yang tidak berbeda nyata terhadap semua bakteri uji (Streptococcus pneumoniae, Klebsiella pneumonia, Staphylococcus aureus dan Staphylococcus epidermidis).

Secara umum hasil penelitian ini menunjukkan potensi ekstrak daun pare yang potensial menghambat pertumbuhan bakteri Streptococcus pneumoniae, Klebsiella pneumonia, Staphylococcus aureus dan Staphylococcus epidermidis penyebab ISPA.

Kemampuan ekstrak daun pare dalam menghambat pertumbuhan masing-masing bakteri uji disebabkan oleh zat aktif yang dikandungnya. Ekstrak daun pare mengandung senyawa flavonoid, saponin, alkaloid, karbohidrat, antosianin, tanin, steroid, glikosida, asam askorbat, $\beta$-karoten, komponen volatil, asam tartrat, asam maleat, asam sitrat, asam suksinat, asam asetat, pektin, dan gula invert ( Doughtari, 2006; Perdana, 2012).

Daun pare paling sering digunakan sebagai obat batuk di masyarakat dengan cara meminum sari perasan daun pare. Secara empiris pengobatan ini akan meredakan batuk dan mengencerkan lendir (sputum). Berdasarkan hasil penelitian, daun pare terbukti berpotensi mengobati batuk dengan mekanisme menghambat pertumbuhan bakteri uji (bakteri penyebab ISPA). Dimana batuk merupakan manfestasi umum dari penyakit ISPA (infeksi saluran napas akut). Beberapa penelitian yang telah menyatakan bahwa Streptococcus pneumoniae, Staphylococcus aureus, Staphylococcus epidermidis dan Klebsiella pneumonia merupakan beberapa jenis bakteri yang terbukti ditemukan sebagai isolate bakteri dalam kultur dahak penderita batuk non tuberkulosis (Panggalo, 2013; Pakadang, 2018). Mekanisme antibakteri yang terjadi dalam penelitian ini adalah merusak permeabilitas dinding sel dan menghambat sintesa DNA bakteri. Mekanisme antibakteri ini diberikan oleh kandungan zat aktif tanaman yang terdiri dari flavonoid, fenol, tannin, saponin, steroid. Potensi tanaman lain yang juga dapat menghambat pertumbuhan bakteri-bakteri penyebab batuk ISPA seperti Streptococcus pneumoniae, Staphylococcus aureus, Klebsiella pneumonia dan Staphylococcus epidermidis juga telah dibuktikan. Tanaman lainnya yang mempunyai komponen zat aktif yang sama sebagai metabolit sekunder ternyata juga terbukti memberikan pengaruh menghambat pertumbuhan bakteri-bakteri uji tersebut. Tanaman tersebut antara lain Miana, buah asam jawa dan Jahe Merah (Pakadang, 2019; Pakadang, 2020).

Zat aktif yang berpotensi dalam pengobatan merupakan metabolit sekunder dari suatu tanaman. Aktivitas antibakteri daun pare terjadi dengan berbagai mekanisme dari masinhg-masing zat aktif yang bekerja secara sinergis. Kelebihan obat herbal ditunjang oleh variasi kandungan zat aktif dimana terjadi efek sinergi (potensiasi) dan berpotensi menurunkan toksisitas dari beberapa senyawa tunggal, sehingga dapat mencegah efek samping dalam pengobatan dan bahkan mencegah kemungkinan terjadinya resistensi obat (Poongothai 2013; Harnani, 2011).

Mekanisme antibakteri golongan senyawa flavonoid adalah menghambat sintesa asam nukleat dalam sel, merusak fungsi membran sel dan menghambat metabolisme energy (Hendra dkk, 2011). Mekanisme antibakteri flavonoid yaitu: menghambat sintesa asam nukleat, menghambat fungsi membran sitoplasma, menghambat metabolisme energi sel, menghambat pembentukan bio-film, menghambat porin chanel membran sel, merubah permeabilitas membran sel. Berdasarkan penelitian Chusnie dan Lamb (2005) mekanisme flavonoid dalam menghambat sintesa asam 
nukleat terjadi pada cincin A dan B (gugus hidroksil di posisi 2',4' atau 2',6' dihidroksilasi pada cincin B dan 5,7 dihidroksilasi pada cincin A). Aktivitas flavonoid seperti quercetin dikaitkan dengan penghambatan enzim girase DNA. Penelitian tersebut juga menunjukkan flavonoid seperti sophoraflavone $G$ dan epigallocatechin gallate dapat menghambat fungsi membran sitoplasma, dan licochalcone A dan $\mathrm{C}$ terbukti menghambat metabolisme energi. Flavonoid lain dengan mekanisme kerja berbeda yaitu robinetin, myricetin, apigenin, rutin, galangin, 2,4,2'-trihydroxy-5'-methylchalcone dan lonchocarpol A. Menurut Nuria dkk (2009) menyimpulkan bahwa flavonoid dapat berinteraksi dengan membran sel yaitu membentuk senyawa kompleks dengan protein bakteri yang dapat merusak membran sel bakteri sehingga senyawa intraseluler keluar dari sel. Mekanisme lain dari flavonoid adalah menghambat fungsi membran sel dengan cara menghambat ikatan enzim ATPase dan phospholipase sehingga permebealitas membran sel menjadi rusak.

Senyawa fenol sebagai salah satu zat aktif dalam daun pare juga berpotensi sebagai antibakteri yaitu membunuh mikroorganisme dengan mekanisme denaturasi protein sel. Pembentukan ikatan hidrogen antara protein dan senyawa fenol berdampak rusaknya struktur protein sel bakteri sehingga mempengaruhi permeabilitas dinding sel dan membran sitoplasma. Rusaknya permeabilitas dinding sel dan membran sitoplasma menyebabkan komponen makromolekul dan ion dalam sel tidak seimbang, sehingga terjadi lisis sel. Kemampuan antibakteri dari senaywa polifenol tergantung pada interaksi antara polifenol dengan permukaan sel bakteri (Chibane et al, 2019).

Kemampuan antibakteri senyawa tanin adalah aglutinasi protein sel bakteri. Tanin berpotensi menginaktifkan adhesin sel mikroba, menginaktifkan enzim, dan menggangu transport protein pada lapisan dalam sel. Selain itu tanin dapat mengganggu pembentukan polipeptida dinding sel sehingga struktur dinding sel menjadi tidak sempurna. Akibatnya terjadi lisis dinding sel akibat tekanan osmotik maupun fisik (Sari dan Sari 2011). Tanin adalah senyawa polifenol dari tumbuhan yang dapat berikatan dengan protein, asam amino, alkaloid dan terjadi pengendapan protein yang dikenal sebagai biomolekul antimikroba. Mekanisme tannin dan komponen zat aktif lainnya yang mempengaruhi potensi ekstrak tanaman sebagai antimikroba terhadap beberapa organisme pathogen baik bakteri Gram positif maupun Gram negatif (Kurkehar, 2016).
Saponin berpotensi sebagai antibakteri dengan mekanisme menurunkan tegangan permukaan dinding sel bakteri sehingga merusak permebialitas membran sel. Sehingga terjadi lisis pada dinding sel sehingga enzim dan protein keluar dari sel. Keluarnya isi sel menyebabkan kematian sel bakteri (Madduluri, 2013). Mekanisme antibakteri senyawa saponin adalah kerusakan dinding dan membran sel yang ditentukan dengan mengukur kadar AKP dan protein terlarut (Khan, 2018).

Senyawa alkaloid dapat mengganggu penyusunan peptidoglikan pada dinding sel bakteri sehingga dinding sel yang terbentuk tidak sempurna dan cenderung terjadi kematian sel. Alkaloid dapat menghambat sintesa DNA dengan menghambat sintesa enzim topoisomerase sel bakteri (Darsana, 2012; Karou, 2005). Alkaloid juga menunjukkan potensi antibakteri dengan menghambat pengangkutan senyawa ATP yang dibutuhkan oleh membran sel. Alkaloid merupakan senyawa potensial yang bertindak sebagai senyawa timbal untuk pengembangan potensi tanaman sebagai antibakteri (Mabhisa et al., 2016).

Potensi steroid sebagai antibakteri sejalan dengan sensitivitas membrane lipid sel terhadap komponen steroid yang menyebabkan terjadinya kebocoran pada liposom. Steroid merupakan senyawa lipofilik yang dapat berinteraksi dengan membran fosfolipid sel yang bersifat permeabel terhadap senyawa-senyawa lipofilik. Interaksi ini menyebabkan struktur membran sel rapuh dan lisis.(Madduluri, 2013; Ahmed dan Bahar, 2007).

\section{KESIMPULAN}

\begin{tabular}{llr}
\multicolumn{2}{c}{ Ekstrak daun pare } & (Momordica \\
charantia L.) berpengaruh & terhadap \\
pertumbuhan & Streptococcus pneumoniae,
\end{tabular} Klebsiella pneumonia, Staphylococcus aureus dan Staphylococcus epidermidis penyebab ISPA berdasarkan potensi menghambat pertumbuhan bakteri. Efektivitas ekstrak daun pare tidak berbeda nyata terhadap semua bakteri uji. Efektivitas ekstrak daun pare konsentrasi 15.000 ppm tidak berbeda nyata dengan amoksisilin 50 ppm.

\section{SARAN}

Disarankan untuk melakukan penelitian lanjutan tentang aktivitas mukolitik dari daun pare untuk pengembangan potensi daun pare sebagai obat batuk penyebab ISPA.

\section{UCAPAN TERIMA KASIH}

Disampaikan terima kasih kepada pimpinan institusi jurusan farmasi Poltekkes 
Kemenkes Makassar dan semua pihak yang telah membantu khususnya dalam pengambilan data di laboratorium mikrobiologi.

\section{DAFTAR PUSTAKA}

Ahmed dan Bahar. 2007. Chemistry Of Natural Products. New Delhi:Department of Pharmaceutical Chemistry Faculty of Science Jamia Hamdard. India.

Aulya, S., 2012. Adsorpsi, Emulsifikasi, dan Antibakteri Ekstrak Daun Pare (Momordica charantia). Skripsi. Departemen Biokimia Institut Pertanian Bogor. Bogor

Chibane L.B., Forquet P., Clement Y., Akkari L.L., Oulahal N., Degraeve P., Borges C., 2019. Antibacterial Properties of Polyphenols: Characterization and QSAR (Quantitative Structure-Activity Relationship) Models. Front Microbiol. 2019; $\quad 10$ : 829. doi: 10.3389/fmicb.2019.00829. PMCID: PMC6482321. PMID: 31057527

Cushnie T. dan Lamb A.J., 2005. Antimicrobial activity of flavonoids International Journal of Antimicrobial Agents 26(5):343-56. DOI: 10.1016/

Darsana I., Besung I., Mahatmi H. 2012. Potensi Daun Binahong (Anredera Cordifolia (Tenore) Steenis) dalam Menghambat Pertumbuhan Bakteri Escherichia coli secara In Vitro. Indonesia Medicus Veterinus.2012.

Doughari J.H. 2006. Antimicrobial Activity of Tamarindus indica Linn, Tropical Journal of Pharmaceutical Research, 5(2) ; 597-603.

Hernani. 2011. Pengembangan Biofarmaka Sebagai Obat Herbal Untuk Kesehatan. Buletin Teknologi Pascapanen Pertanian. 2011; 7(1): 20-29.

Hendra R, Ahmad S, Sukari A, Shukor MY, Oskoueian E. 2011. Flavonoid analyses and antimicrobial activity of various parts of Phaleria macrocarpa (Scheff.) Boerl fruit. Int J Mol Sci. 2011;12: 3422-3431

Karou D. Dan Savadogo A. 2005. Antibacterial activity of alkaloids from Sida acuta. African Journal of Biotechnology. 2005.4(12): 1452-1457.

Kementerian Kesehatan RI, 2011. Pedoman pengendalian infeksi saluran pernapasan akut. ISBN : 978-602-235046-0. Direktur Jenderal Pengendalian Penyakit dan Penyehatan Lingkungan. Kementerian Kesehatan RI. Jakarta.

Kementerian Kesehatan RI, 2011. Pedoman pencegahan dan pengendalian Infeksi Saluran pernapasan akut (ISPA). Direktur Jenderal Pencegahan dan Pengendalian Penyakit. Kementerian Kesehatan RI. Jakarta.

Khan M.I., Ahhmed A., Shin J.H., Baek J.S, Kim M.Y., Kim J.D., 2018. Green Tea Seed Isolated Saponins Exerts Antibacterial Effects against Various Strains of Gram Positive and Gram Negative Bacteria, a Comprehensive Study In Vitro and In Vivo. Hindawi. Evidence-Based Complementary and Alternative Medicine :Volume 2018, Article ID 3486106, 12 pages https://doi.org/10.1155/2018/3486106

Mabhiza D., Chitemerere T., Mukanganyama S. 2016. Research Article Antibacterial Properties of Alkaloid Extracts from Callistemon citrinus and Vernonia adoensis against Staphylococcus aureus and Pseudomonas aeruginosa. Hindawi Publishing Corporation International Journal of Medicinal Chemistry Volume 2016, Article ID 6304163, 7 pages http://dx.doi.org/10.1155/2016/6304163.

Madduluri S., Rao K.B., Sitaram B. 2013. In Vitro Evaluation of Antibacterial Activity of Five Indegenous Plants Extract Against Five Bacterial Pathogens of Human. International Journal of Pharmacy and Pharmaceutical Sciences.2013:5(4): 679-684.

Nuria M.C., Faizaitun A.S. 2009. Uji Aktivitas Antibakteri Ekstrak Etanol Daun Jarak Pagar (Jatropha Curcas L) Terhadap Bakteri Staphylococcus aureus ATCC 25923, Escherichia coli ATCC 25922, dan Salmonella typhi ATCC 1408, Mediagro. 2009; 5(2): 26-37.

Pakadang S.R. dan Salim H. 2019. Kombinasi Daun Miana (Coleus scutellarioides (L.) Benth) dan Rimpang Jahe (Zingiber officinale Rosc.) sebagai antibakteri Streptococcus pneumonia, Staphylococcus aureus, Staphylococcus epidermidis, Klebsiella pneumonia Penyebab Batuk. Media Farmasi 
P.ISSN 0216-2083. E ISSN 2622-0962 vol XV no. 1, April 2019. DOI: https://doi.org/10.32382/mf.v15i1.779

Pakadang S.R., 2018. Potential of Miana Leaves (Coleus scutellarioides (L.) Benth) As an Antibacterial Streptococcus pneumonia, Staphylococcus aureus, Staphylococcus epidermidis, Klebsiella pneumonia from Sputum Cough Patients in Makassar City. Proceeding 1st. International Conference Health Polytechnic of Kupang, 122-131. Retrieved from http://proceeding.poltekeskupang.ac.id/ index.php/ichpk/article/view/45

Pakadang S.R. dan Salim H. 2020. Sensitivitas Streptococcus

Staphylococcus pneumoniae, Staphylococcus epidermidis terhadap Buah Asam Jawa (Tamarindus indica L). Media Farmasi P.ISSN 0216-2083. E ISSN 2622-0962 vol XVI no. 1, April $2020 . \quad$ http://journal.poltekkesmks.ac.id/ojs2/index.php/mediafarmasi /article/view/1407/942

Panggalo, TJ., Porotu'o, J., dan Buntuan, V. 2013. "Identifikasi Bakteri Aerob Pada Penderita Batuk Berdahak Di Poliklinik Interna BLU RSUP Prof. dr. R. D. Kandou Manado". Jurnal e-Biomedik Volume 1 Nomor 1, hlm. 408-413.

Poongothai P. Dan Rajan S. 2013. Antibacterial Properties of Mangifera indica flower extracts on Urophatogenic Escherichia coli,.International Journal of Current Microbiology and Aplied Science. 2013; 2(12): 104-111

Puspodewi. 2015. Daya hambat daun Asam Jawa (Tamarindus indica L) Terhadap Pertumbuhan Salmonella typhi Penyebab Demam tifoid. Skripsi. unimus press.semarang.

Sari, F.P. dan S. M. Sari. 2011. Ekstraksi Zat Aktif Antimikroba dari Tanaman Yodium (Jatropha multifida Linn) sebagai Bahan Baku Alternatif Antibiotik Alami. Skripsi. Fakultas Teknik Universitas Diponegoro. Semarang.

World Health Organization. 2008. Epidemicprone \& pandemic-prone acute respiratory diseases: Infection prevention \& control in health-care facilities. Summary guidance 2007
WHO/CDS/EPR/2007.8 (C) World Health Organization. Jenewa.

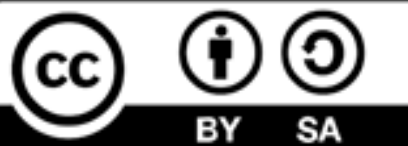

